\title{
CORPORATE GOVERNANCE DISCLOSURE AND EARNINGS QUALITY: STUDY ON COMPANIES LISTED ON THE ASEAN STAR FINANCIAL TIMES STOCK EXCHANGE (FTSE)
}

\author{
Robick Faliana* and Wiwik Utami \\ Mercu Buana University, Indonesia
}

\begin{abstract}
The governance mechanism is different for each company. Therefore, companies need an indicator to measure the quality of governance and one of them is the ASEAN Scorecard. This indicator is used as a standard for measuring the quality of corporate governance in the ASEAN region. The corporate governance mechanism can be a factor in price changes in the stock market. Investors will react to any issues related to it. Price changes that occur on the stock market are a measure of the size of investors in investing because they can affect expected earnings. Although there is quite a lot of research related to it, research on earnings quality that discusses market response to price changes that occur due to the influence of governance mechanisms is limited. This study aimed to examine the effect of corporate governance on earnings quality using companies listed on the Financial Time Stock Exchange ASEAN Star (FTSE ASEAN Star). The study was conducted by examining financial ratios of companies using a cross-sectional data regression model with the Earnings Response Coefficient (ERC) as a proxy. The results showed that corporate governance affected ERC, especially on the disclosure of corporate governance and shareholder rights.
\end{abstract}

Keywords: ASEAN scorecard, corporate governance, earnings response coefficient, disclosure, fraud

\section{ARTICLE INFO}

\section{Article History:}

Received: 16 September 2020

Accepted: 9 July 2021

Published: 31 August 2021

* Corresponding Author: Robick Faliana. E-mail: obay.faliana.2000@gmail.com 


\section{INTRODUCTION}

Company bankruptcies in 2007-2008 in the banking and non-banking sectors, especially in developing countries, led to increased investor distrust of the corporate financial system, and this is in accordance with what is recommended by the United Nations Conference on Trade and Development (UNCTAD) (2010). The impact that occurs due to increased investor distrust is the growing level of investor awareness of the need for deeper analysis of financial reports, especially when investing. On the other hand, it forces more responsibility on business actors to improve company reports into quality and credible ones. To be able to meet these needs, business actors need to apply procedures or rules in accordance with the principles of good corporate governance.

The importance of corporate governance for investors has been proven in various studies. Shleifer and Vishny (1986) stated that corporate governance provides an informative picture of the condition of a company. Likewise, Kasim (2015) stated that one of the determinants of the quality of financial statements is the application of corporate governance. This was reinforced by Zhai and Wang (2016) who stated that when the governance environment is bad, it will result in a bad relationship between the quality of accounting information and the choice of investment capital. The studies mentioned above reinforce the statement regarding the role of governance in relation to corporate reports, especially in financial reports, and this is important for investors.

The implementation of good governance will involve the relationship of business activities between shareholders and other stakeholders. This is in line with the research by Norwani et al. (2011). However, in practice, shareholders are more likely to delegate policy authority to management and directors. Delegation of authority is not always good for shareholders. Delegation of authority can create agency conflicts that can harm a company. Agency conflicts may arise when there are conflicts of interests between the owners and the delegated people (such as managers) of the business. (Banks, 2004).

Agency conflicts allow delegated people to commit fraud in the preparation of financial reports, especially those related to company income. 
This person may manipulate company profits to influence capital market transactions as described in Dechow and Schrand's (2004) research on earnings management. Earnings management is interpreted differently by Ronen and Yaari (2008). They interpret earnings management in terms of financial reporting results as a collection of managerial decisions that result in incorrect short-term financial reporting in terms of maximizing the value of earnings. Related to this, managerial activities in earnings management produce an indication of the difference in the level of earnings to high-quality earnings and low-quality earnings.

The existence of differences in earnings quality raises thoughts about the possibility of corporate fraud protection in corporate governance practices, especially in reporting financial statements as stated by Mangala and Kumari (2015). This is often found not only in developed countries but also in developing countries. Ugbede et al. (2013) stated that large differences occur in corporate governance practices and disclosure standards in stock exchange markets in developed and developing countries even though governance is defined the same in each company.

Research conducted by Ugbede et al. (2013) provides inspiration to conduct further research related to corporate governance in developing countries, especially the Southeast Asian region. The Association of South East Asia Nations (ASEAN) is an association consisting of countries in the Southeast Asian region. ASEAN has a method of measuring corporate governance known as the ASEAN Corporate Governance Scorecard (ASEAN CGSC). So by referring to the research of Ugbede et al. (2013), there is a possibility of differences in governance practices in public listed companies in ASEAN even though the measurement of corporate governance is carried out using the ASEAN CGSC. Evidence of the results of differences in corporate governance scores in public listed companies of ASEAN countries is found in the annual report on the implementation of corporate governance which is published by ASEAN once a year. The difference in the results of corporate governance scores allows the potential for fraud to happen in the implementation of governance even though the implementation of governance is carried out according to the rules in the ASEAN CGSC. 
Therefore, this research was conducted in relation to mitigating the potential for corporate fraud due to the implementation of bad corporate governance practices in ASEAN. The Earnings Response Coefficient (ERC) method was used to measure the quality of earnings as a proxy for financial statements. Thus, ERC is expected to be a fraud mitigation tool due to the implementation of bad corporate governance. Like Mahjoubi and Abaoub (2015) who conducted research on measuring earnings quality using the ERC, and also research conducted by Demerjian et al. (2013), Hashim and Devi (2012), Kamarudin et al. (2012), Latif et al. (2017), and Gaio and Raposo (2014) regarding the potential for agency conflicts over corporate earnings reports that can occur due to the possible influence of corporate governance practices on earnings.

\section{LITERATURE REVIEW}

\section{Corporate Governance}

Governance is defined variously by experts based on research results. According to the International Finance Corporation (IFC) in 2010, the notion of governance is highly dependent on the results of governance research on an institution, country, and legal traditions. The results of a survey on the definition of corporate governance published by Solomon and Solomon (2004) state that the supervisory and control process to ensure and / or control corporate management actions in accordance with the interests of shareholders is the definition of corporate governance of the majority of correspondents. The survey results reinforce the IFC and World Bank's (2005) definition of governance which states that governance is the system by which companies are directed and controlled.

Codes of practice and governance principles related to corporate governance are largely developed focusing on the role of the company's board of directors. Of the several codes of practice and governance principles, only the principles of the Organization for Economic Cooperation and Development (OECD) are capable of dealing with policy makers and businesses and focus on the entire corporate governance framework including the rights of shareholders, stakeholders, disclosures and director practices. The principles of corporate governance under the OECD have 
been widely accepted worldwide as a framework and reference point for corporate governance and provide guidance on the principles of good governance.

There are four core values in the OECD corporate governance framework, namely: Fairness, Responsibility, Transparency and Accountability. The concerns of the OECD framework are:

1. The corporate governance framework must protect shareholder rights and ensure fair treatment of all shareholders.

2. The corporate governance framework should recognize stakeholder rights established by law and encourage active collaboration between companies and stakeholders in creating wealth, jobs and the sustainability of sound financial companies.

3. The corporate governance framework must ensure timely and accurate disclosure of all material matters relating to the company, including its financial situation, governance structure, performance, and ownership.

4. The corporate governance framework should ensure the company's strategic guidance, effective monitoring of management by the board, and accountability of the board to the company and its shareholders.

Basically, when a corporate governance is considered a failure, it will cause a company to report its failure. This is in accordance with the research of Norwani et al. (2011) which states that failure in governance can result in failure in reporting.

\section{Earnings Management and Earnings Quality}

Based on research by Ronen and Yaari (2008), earnings management is defined as a collection of managerial decisions that result in financial reporting errors in an effort to maximize the value of earnings. In this case, shareholders may not know whether the reports provided by the earnings manager have been amended or not. The practice of earning management actions based on Ronen and Yaari (2008) includes earnings management which is carried out through: 
1. An acceptable choice under general accounting procedures.

2. A decision on adopting a new standard in financial reporting.

3. A decision call when general accounting procedures require estimation.

4. A classification of goods as above or below the line of operating income (or income from continuing operations) to separate continuing profits from temporary income.

5. Structuring transactions to achieve the desired accounting results.

6. Time recognition through income and expenses, and decide whether to utilize costs.

7. Production and investment decisions.

8. Manage the transparency of the presentation of financial statements

9. Managing earnings informativeness in various ways.

They also argue that the things that underlie earnings management must be viewed from several perspectives, namely:

1. Providing benefits, which is a signal of long-term value

2. Destructive, which is hiding short-term or long-term value

3. Neutral, namely expressing short-term performance correctly.

Earnings management consists of earnings information which is the main element in financial statements. Earnings information is also very important because it has a predictive value. This is in accordance with the research of Dechow and Schrand (2010) regarding the statement of financial accounting concepts. Because it has predictive value, the profit generated by a company can be divided into high-quality profit and low-quality profit. Related to this, the measurement of earnings quality can be carried out based on investor response according to research by Francis et al. (2006).

Research on earning quality measurement based on investor response is not as much research based on an accrual basis. The difference does not lie in the perspective of the object of research carried out but with the same goal of measuring earnings quality. Measuring earnings quality based on investor responses to earnings information is also known as the Earnings Response Coefficient (ERC). ERC is proxied by beta coefficient on delta price and delta earning per share. 
According to research by Francis et al. (2006), measuring the quality of earnings using the ERC can be done by measuring the estimated slope coefficient at the level of change in earnings. A high or low slope coefficient value indicates a high or low investor response to changes in earnings value. The higher the investor's response to earnings information, the better the earnings quality. Conversely, the lower the investor's response to earnings information, the lower the earnings quality. In other words, in line with Mahjoubi and Abaoub (2015), measurement of earnings quality based on the ERC is a market reaction in terms of unexpected price changes according to the unit of profit.

\section{Earnings Quality and Corporate Governance}

Several studies on governance issues have been carried out as in Norwani et al. (2011), Hashim and Devi (2012), Uwuigbe et al. (2014), Kasim (2015), Ugbede et al. (2013), Cupertino et al. (2015), Kazemian and Sanusi (2015), Okolie (2014), Zhai and Wang (2016), Mahjoubi and Abaoub (2015), Noor et al. (2015), Bukit and Nasution (2015), and Mansor et al. (2015). They conducted research related to the impact of the failure of corporate governance on the application of financial reports, the effect of corporate governance, earnings governance and management, as well as the quality of financial reports and the effect of corporate governance and earnings quality as an intervening variable.

Several studies that provide positive results on the effect of governance on earnings quality include research conducted by Demerjian et al. (2013) which showed that there is a positive influence between managerial capability on earnings management. Hashim and Devi (2012) and Kamarudin et al. (2012) showed a significant positive effect between institutional supervision and CEO quality on earnings quality. Latif et al. (2017) showed that corporate governance and earnings quality influence company value.

But on the other hand, research conducted by Gaio and Raposo (2014) found that corporate governance ratings have a negative and significant relationship with earnings quality. This suggests that there are other possible proxies that do not always show a positive influence between governance and earnings quality. One of the possibilities referred to is when using the 
ERC as a proxy for earnings quality. Although there are several studies on the ERC as a proxy for earnings quality such as those conducted by Francis et al. (2006) and Mahjoubi and Abaoub (2015), there are still few studies using the ERC as a proxy for earnings quality on governance. This may occur because there have been predictions about the research results that may not be as expected, and are more likely to be negative because the measure of the ERC earnings quality is based on investor responsiveness which is an objective assessment of investors based on elements of investment decisions.

\section{Fraud and Corporate Governance}

Fraud in a company is usually called Corporate Fraud. Mangala and Kumari (2015) defined fraud according to the Standard on Auditing (SA 40) as an intentional act by one or more individuals including management, people responsible for governance, and employees or third parties using deceptive methods to make a profit. In other words, fraud cannot be justified in a corporation because it indirectly harms the company.

Fraud in corporate governance usually occurs in governance practices and can be detected by analyzing company reports, especially financial reports. In their research, Mangala and Kumari (2015) stated that the initial signals to detect and prevent fraud are known as red flags which indicate motivation and opportunities for potential fraud to occur. The types of corporate fraud that need to be detected are misuse of assets and fraud in reporting financial statements.

\section{The ASEAN Corporate Governance Scorecard (ASEAN CGSC)}

Governance for ASEAN is carried out to encourage the development of an integrated capital market in ASEAN. The measurement of governance ratings is prepared based on the methodology applicable in ASEAN countries and multilateral institutions such as the OECD.

The scorecard that has been prepared by these experts are called the ASEAN Corporate Governance Scorecard (ASEAN CGSC) where there are two levels of scoring in determining the score, namely level 1 and level 2. Level 1 consists of five main parts that are in accordance with the principles of governance by the OECD. Level 2 consists of two additional parts, namely bonuses and penalties. The following is an explanation of the details: 


\section{A. Level 1}

\section{Shareholders' rights}

The ASEAN CGSC in terms of shareholder rights refers to the OECD principles regarding shareholder rights. Regarding earnings quality, research conducted by Huang et al. (2010) found that stronger shareholder rights can deter managers from reporting aggressive earnings. The results of research by Huang et al. (2010) are reinforced by research by Ngamchom (2015) and strengthen the Agency Theory and agency conflict which states that managers can do as they wish if there is no good control. The existence of shareholder intervention indicates the possibility of emphasis on the manipulation of corporate reporting that may occur, especially financial reporting carried out by the person who made the report. However, manipulation can also occur if there is desire or pressure from shareholders.

\section{Fair treatment of shareholders}

With regard to fair treatment of shareholders, the ASEAN CGSC refers to the OECD principles regarding a corporate governance framework that must provide fair treatment to all shareholders. If shareholders are defined as all the components involved in the company, then there is an influence between fair treatment of shareholders on earnings quality. This is in line with research related to the correlation between shareholders and profit components, including Huang and Xue (2016) who show the relationship between earnings management in companies and ownership that focuses on earnings results, especially when shareholders have an incentive to do so. Also, Ali and Lesage's (2013) stated that there is a positive influence between audit fees and institutional ownership.

\section{The role of stakeholders}

The role of stakeholders is considered as one of the important points in the ASEAN CGSC. This is consistent with the OECD-based corporate governance framework on the role of stakeholders. The role of stakeholders must be in line with their fiduciary principles and duties. This is in line with Friedman and Miles (2006) regarding the meaning, principles and obligations of fiduciary. If the principles and duties of fiduciary are not implemented properly, it can damage the 
good relationship between company managers and other stakeholders in a company. When this happens, it is possible that the company's atmosphere can be disrupted, allowing for earnings management. This is in line with Bukit and Nasution (2015) who stated that when a company has different employees and has excess cash, there is the possibility for earnings manipulation by the earnings manager.

\section{Disclosure and transparency}

Disclosure and transparency in the ASEAN CGSC ensure that all matters relating to company corporate reports must be ensured to contain appropriate disclosures as well as accurate timing and transparent results. This is in line with the OECD framework on disclosure and transparency. The relationship between disclosure and transparency with earnings quality is when management discloses company reports that are not in accordance with the actual conditions of the company, especially if it is related to certain techniques used by management to hide or manipulate everything related to the earnings component. This is in line with research by Omar et al. (2014) on earnings management and disclosure by management.

\section{Responsibilities of the board}

The board's responsibility for corporate governance lies in strategic guidance, monitoring management and business activities, as well as corporate and shareholder accountability. This is accommodated by the ASEAN CGSC in line with the OECD principles. Board decisions may not match the expectations of the executive management, so there can be agency conflicts from the side of the executive management as an agent of the board. On the other hand, the executive management may take actions beyond the normal limits as determined by the company. That's where the board plays important roles in the company. They may hamper the tendency of the executive management to engage in matters relating to unexpected fraud such as those associated with earnings management. This is in line with Xie et al. (2001) on the activities of the board of directors and the audit committee. The board of directors and the audit committee as part of the board are important components in inhibiting the tendency of unexpected earnings management to occur. Thus, the quality of earnings can be maintained by the directors for reporting purposes to investors in order to remain in a good position. 


\section{B. Level 2}

\section{Bonus}

There are at least more than 100 criteria in the ASEAN CGSC which are used as a benchmark for assessing the quality of GCG in companies in ASEAN countries. Bonuses or added value are given if a company carries out corporate governance activities that exceed these standard criteria.

\section{Penalties}

Apart from bonuses, the ASEAN CGSC also has criteria for penalties. Penalties are given if a company carries out corporate governance activities that are not in accordance with or less than the standard. The penalty value will reduce the accumulated criteria and bonus scores. Thus, it is hoped that the measurement of corporate governance based on the ASEAN CGSC will have high credibility that can be accounted for internationally.

\section{METHODOLOGY}

\section{Research Questions and Hypothesis}

The research was conducted by considering the possibility of differences in earnings quality in companies managing corporate governance. The object of this research were companies listed on the Financials Time Stock Exchange ASEAN Star as one of the official stock exchanges for companies in ASEAN countries. The number of companies studied was less than 30 companies in each ASEAN country, using the ASEAN CGSC as a proxy for corporate governance and the ERC as a proxy for earnings quality.

There were two research questions in this study. The first question was "Does disclosure of corporate governance using the ASEAN CGSC affect the earnings quality of companies registered with public listed companies in ASEAN countries?", and the second question was "Which elements of assessment of the ASEAN CGSC affected the earnings quality of companies registered with public listed companies in the ASEAN countries?" 
The research was conducted on the basis of six hypotheses $(\mathrm{H})$ to answer the above questions and examine the relationship between corporate governance and earnings quality, namely:

H1: Shareholder rights have a significant effect on earnings quality

Strong shareholder rights may lead to the possibility of profit. This is in accordance with Huang et al. (2010) which is related to Ngamchom (2015) on stronger shareholder rights that can restrain stakeholders from reporting aggressive earnings. This research is the basis for the hypothesis about the effect of shareholder rights on earnings quality.

H2: Equitable Treatment has a significant effect on earnings quality

The application of fair treatment can increase costs leading to an increase or decrease in earnings quality based on Huang and Xue (2016) and Ali and Lesage (2013) on shareholder returns. This research is the basis for the hypothesis about the effect of fair treatment on earnings quality.

H3: The role of stakeholders has a significant effect on earnings quality

Policies issued by stakeholders may be carried out in an effort to influence earnings quality. This is in accordance with Friedman and Miles (2006) on the role of stakeholders and fiduciaries as explained by Bukit and Nasution (2015) about the possibility of earnings by earnings managers. Based on this research, a hypothesis about the influence of the role of stakeholders on earnings quality emerged that needed to be studied further.

H4: Disclosure and transparency have a significant effect on earnings quality

Management may disclose company reporting that is not in accordance with actual company conditions. So it could be that the quality of reported earnings is also different from the actual conditions. This is in line with Omar et al. (2014) on earnings management and management by management. On this basis, a hypothesis about the effect of implementation and transparency on earnings quality arose that needed to be studied further. 
H5: The responsibility of the board has a significant effect on earnings quality.

Management actions can affect the risk that harms a company. Therefore, the responsibility and oversight of the board becomes another important factor in the probability of making a profit. This is in accordance with Xie et al. (2001) on the activities of the board and audit committee.

H6: Total disclosure has a significant effect on earnings quality.

Overall, corporate governance has an important role in managing earnings with both a rising and a falling quality. This is in accordance with Mahjoubi and Abaoub (2015) on the effect of corporate governance on earnings quality. An increase or decrease in earnings quality due to the implementation of corporate governance is the basis for the hypothesis about the effect of corporate governance disclosure on earnings quality.

\section{Research Model and Measurement}

This study used an explanatory-causality method with cross section data analysis using multiple linear regression models using more than one independent variable. The units of analysis used in this research were:

1. Disclosure of corporate governance and its components obtained from the ASEAN Corporate Governance Scorecard which included Shareholder Rights, Equal Treatment of Shareholders, Roles of Stakeholders, Disclosure and Transparency, and Responsibilities of the Board.

2. Earnings Response Coefficient (ERC) which was used as a proxy for measuring earnings quality.

3. Return on Assets (ROA) as a control variable which is the result of financial asset reports, Debt Equity Ratio (DER) as a control variable which is the result of debt-equity financial reports, and Debt Long Term Ratio (DLTR) as a control variable which is the result of the report of long term financial loans. 
The measurement of earnings quality using the ERC used in this study was based on the research formulation model of Mahjoubi and Abaoub (2015), as follows:

$$
\Delta \mathrm{Pt} / \mathrm{Pt}-1=\alpha+\beta \Delta \text { epst } / \mathrm{Pt}-1+\varepsilon i t .
$$

Where Pt: Is a stock price at a certain time $\mathrm{t}, \Delta \mathrm{Pt}$ : Variant of stock price between time t-1 and t, $\Delta$ epst: Variants of earnings per share between time t-1 and t, eit: Residual conditions. According to Mahjoubi and Abaoub (2015) the model is able to measure ERC based on the delta of stock prices and delta earnings per share (EPS) of a company. ERC in the equation is indicated by the beta coefficient $(\beta)$ and the time $t$ used in the measurement is on an annual basis. Because the value obtained in Delta EPS and delta stock prices are in units of share value, the resulting beta coefficient can be very small. Similarly results in the research of Latif et al. (2017).

The model used to determine the value of corporate governance based on the ASEAN CGSC was as follows:

$$
\text { GCG_D }=\text { RoSh }+\sum \text { ETS }+\sum \text { RoSt }+\sum \mathrm{DT}+\sum \mathrm{RtB}+\left(\sum \mathrm{Bns}-\sum \mathrm{Pnlt}\right)
$$

Where GCG_D is for Corporate Governance Disclosure score, RoSh is for Right of the Shareholder score, ETS is for Equitable Treatment of the Shareholder score, RoSt is for Role of the Stakeholders score, DT is for Disclosure and Transparency score, RtB is for Responsibilities of the Board score, Bns is for Bonus score, and Pnlt is for Penalty score.

Each element of the measurement of corporate governance was determined based on the 2014 ASEAN Scorecards, as follows:

(1). $\operatorname{RoSh}=(10 / 25) \times \sum Q ;(2) . \operatorname{ETS}=(15 / 17) \times \sum Q ;(3)$. RoSt $=$ $(10 / 21) \times \sum Q ;(4)$. DT = (25/41) x $\sum \mathrm{Q} ;(5)$. RtB = (40/75) x $\sum \mathrm{Q} ;(6)$. Bns $=(11 / 28) \times \sum \mathrm{Q} ;(7)$. Pnlt $=(50 / 21) \times \sum \mathrm{Q}$

Where Q: disclosure value 


\section{Research Data}

The data used in this study were annual financial reports and corporate governance disclosures in the FTSE ASEAN Star for the 2014-2015 period. The number of companies that became research samples after data normalization were 60 companies from 180 companies. The number of companies was divided into: 14 companies in Singapore, 11 companies in Thailand, 11 companies in the Philippines, 12 companies in Indonesia, and 12 companies in Malaysia. Companies from Vietnam were not included in the sample because there were no annual reports written in English for the majority of companies.

\section{Research Analysis}

The research analysis technique used was multiple linear regression model. The model was divided into 2 (two) model components, namely X1 to $\mathrm{Y} 1$ and $\mathrm{X} 2$ to $\mathrm{Y} 2$. Where $\mathrm{X} 1$ were the elements of corporate governance and $\mathrm{X} 2$ were disclosures of corporate governance with control variables whereas Y1 and Y2 were proxies for earnings quality, namely the ERC. Both models are described in the framework as follows:

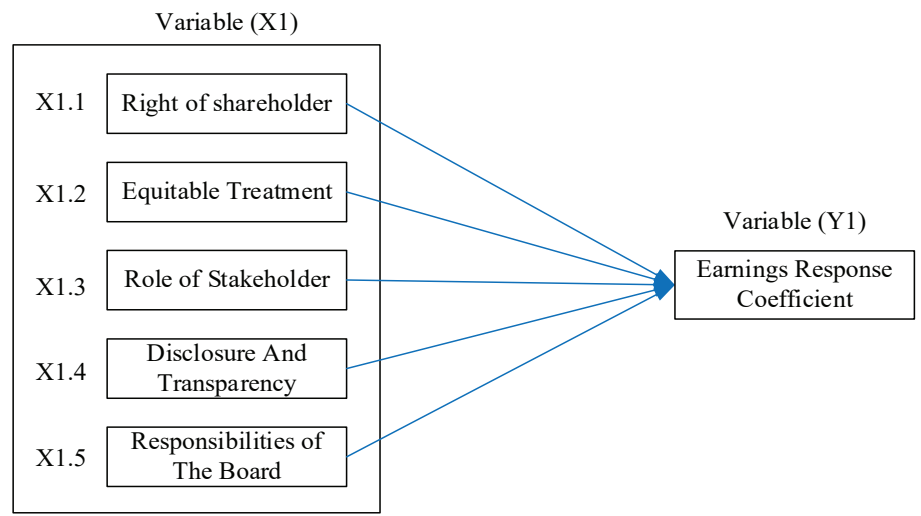

Figure 1: Framework for GCG Elements Against ERC 


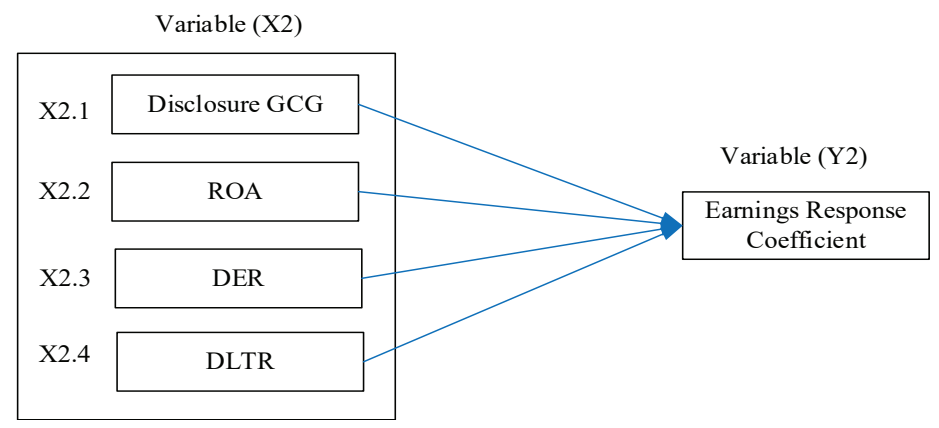

Figure 2: Framework for Disclosure of GCG and Control Variable Against ERC

Figures 3 and 4 show the framework of the research conducted. Thus, based on the two framework, the regression equation model is obtained as follows:

1. $\mathrm{X} 1$ regression model against $\mathrm{Y} 1$ (GCG elements against ERC) $\mathrm{ERCi}=\alpha+\beta 1$ RoShi $+\beta 2 \mathrm{ETSi}+\beta 3 \mathrm{RoSti}+\beta 4 \mathrm{DTi}+\beta 5 \mathrm{RtBi}+\varepsilon \mathrm{Ei}$

2. $\mathrm{X} 2$ regression model against $\mathrm{Y} 2$ (GCG disclosure to ERC) $\mathrm{ERCi}=\alpha+\beta 1 \mathrm{GCG} \_\mathrm{Di}+\beta 2 \mathrm{ROAi}+\beta 3 \mathrm{DERi}+\beta 4 \mathrm{DLTRi}+\varepsilon \mathrm{i}$

Where ERC: Earnings Response Coefficient, $\alpha$ : Constanta Ei: Residual conditions.

\section{RESULTS AND DISCUSSION}

Analysis of data included descriptive analysis, the F-Test, analysis of the determination (R2)-Test, and analysis of the coefficients regression for each component of the study.

\section{Descriptive Analysis}

The processed data was data that had been normalized so that the data did not become biased and met the test requirements. The data tested was data on elements of corporate governance according to the ASEAN 
CGSC including rights of shareholders (RoSH), equitable treatment of shareholders (ETS), role of stakeholders (RoSt), disclosure and transparency (DT), responsibilities of the board (RtB), corporate governance disclosure (GCG_D), return on assets (ROA), debt long term ratio (DLTR), debt equity ratio (DER), earnings response coefficient (ERC). The results are as shown in Table 1 below:

Table 1: Descriptive Statistics

\begin{tabular}{lrrrrr}
\hline & N & Minimum & Maximum & Mean & $\begin{array}{c}\text { Std. } \\
\text { Deviation }\end{array}$ \\
\hline RoSh & 115 & 2.80 & 8.80 & 6.9113 & 1.31874 \\
ETS & 115 & 4.42 & 14.13 & 11.9869 & 2.24762 \\
RoSt & 115 & 4.28 & 10.00 & 7.9390 & 1.46932 \\
DT & 115 & 8.53 & 23.14 & 18.3080 & 3.53986 \\
RtB & 115 & 10.68 & 37.91 & 28.2091 & 5.80808 \\
GCG_D & 115 & 40.43 & 110.18 & 84.2663 & 15.17182 \\
ROA & 115 & -.0322 & .4720 & .080357 & .0818498 \\
ROE & 115 & -.1154 & 3.3198 & .249443 & .5103856 \\
DLTR & 115 & 0.0000 & .4851 & .201803 & .1295131 \\
DER & 115 & .1990 & 12.3369 & 1.619191 & 1.6293418 \\
ERC & 115 & -.00055 & .00069 & -.0000007 & .00024820 \\
Valid N & 115 & & & & \\
(listwise) & & & & & \\
\hline
\end{tabular}

Table 1 shows the minimum, maximum, mean, and standard deviation values for the sample data. From these results, it can be seen that the ERC value which is the coefficient of beta delta earnings per share and delta stock price was very small. This was possible because the sample of earnings per share and stock price used was the value of earnings per share and annual stock price for each object of research.

\section{F-Test}

The F-Test was conducted on two research components, namely corporate governance elements and disclosure of corporate governance. The results of both are shown in the following table: 
Table 2: ANOVA of Corporate Governance Elements

\begin{tabular}{llrrrrr}
\hline Model & & $\begin{array}{c}\text { Sum of } \\
\text { Squares }\end{array}$ & df & \multicolumn{1}{c}{$\begin{array}{c}\text { Mean } \\
\text { Square }\end{array}$} & \multicolumn{1}{c}{ F } & \multicolumn{1}{c}{ Sig. } \\
\hline 1 & Regression & .000 & 5 & .000 & 2.595 & $.029^{\mathrm{b}}$ \\
& Residual & .000 & 109 & .000 & & \\
& Total & .000 & 114 & & & \\
\hline
\end{tabular}

a. Dependent Variable: ERC

b. Predictors: (Constant), RtB, RoSt, DT, RoSh, ETS

Table 2 shows the results of the ANOVA test with a $F$ value of 2.595 . The value of the table $\mathrm{F}$ obtained with a $5 \%$ probability was 2.305 . Hypothesis $\mathrm{H}_{0}$ was accepted because the value of $\mathrm{F}=2.595>$ table value $=2.305$. The sum of squares results, and mean squares showed a fit data model and the sample mean was consistent with the population average.

Table 3: ANOVA of Disclosure of Corporate Governance

\begin{tabular}{llrrrrr}
\hline Model & & $\begin{array}{c}\text { Sum of } \\
\text { Squares }\end{array}$ & df & \multicolumn{1}{c}{$\begin{array}{c}\text { Mean } \\
\text { Square }\end{array}$} & \multicolumn{1}{c}{ F } & \multicolumn{1}{l}{ Sig. } \\
\hline 1 & Regression & .000 & 5 & .000 & 2.906 & $.017^{\mathrm{b}}$ \\
& Residual & .000 & 109 & .000 & & \\
& Total & .000 & 114 & & & \\
\hline
\end{tabular}

a. Dependent Variable: ERC

b. Predictors: (Constant), DER, GCG_D, DLTR, ROA, ROE

Table 3 shows the results of the ANOVA test with a $F$ value of 2.906. The value of the table $\mathrm{F}$ obtained with a $5 \%$ probability was 2.545 . Hypothesis $\mathrm{H}_{0}$ was accepted because the value of $\mathrm{F}=2.906>$ table value $=2.454$. The sum of squares results and mean squares showed a fit data model and the sample mean was consistent with the population average.

\section{Determination $\left(\mathbf{R}^{2}\right)$}

Determination $\left(\mathrm{R}^{2}\right)$ was also conducted on two research components, namely, corporate governance elements and disclosure of corporate governance. The results of both are shown in the following table: 
Table 4: Model Summary of Corporate Governance Elements

\begin{tabular}{lrrrr} 
Model & R & R Square & $\begin{array}{c}\text { Adjusted } \\
\text { R Square }\end{array}$ & $\begin{array}{c}\text { Std. Error } \\
\text { of the } \\
\text { Estimate }\end{array}$ \\
\hline 1 & $.326^{\mathrm{a}}$ & .106 & .065 & .00023995 \\
\hline a. Predictors: (Constant), RtB, RoSt, DT, RoSh, ETS
\end{tabular}

As shown in Table 4 the $\mathrm{R}^{2}$ value was $10.6 \%$ which meant that ERC can be explained by corporate governance elements (Rights of Shareholders, Equitable Treatment of Shareholders, Role of Stakeholders, Disclosure and Transparency, Responsibilities of the Board) while the remaining 89.4\% are explained by other factors outside the research.

Table 5: Model Summary of Dis clos ure of Corporate Governance

\begin{tabular}{llrrrr}
\hline Model & R & R Square & $\begin{array}{c}\text { Adjusted } \\
\text { R Square }\end{array}$ & $\begin{array}{c}\text { Std. Error } \\
\text { of the } \\
\text { Estimate }\end{array}$ \\
\hline 1 & $.343^{\mathrm{a}}$ & .118 & .077 & .00023843 \\
\hline
\end{tabular}

a. Predictors: (Constant), DER, GCG_D, DLTR, ROA, ROE

As shown in Table 5 the $\mathrm{R}^{2}$ value was $8.7 \%$ which meant that the ERC explained by the Disclosure of Corporate Governance was $11.8 \%$ while the remaining $88.2 \%$ are explained by other factors outside the research.

\section{Coefficients Regression}

Coefficients regression was also conducted also on two research components, namely corporate governance elements and disclosure of corporate governance. The results of both are shown in the following table: 
Table 6: Coefficients of Corporate Governance Elements

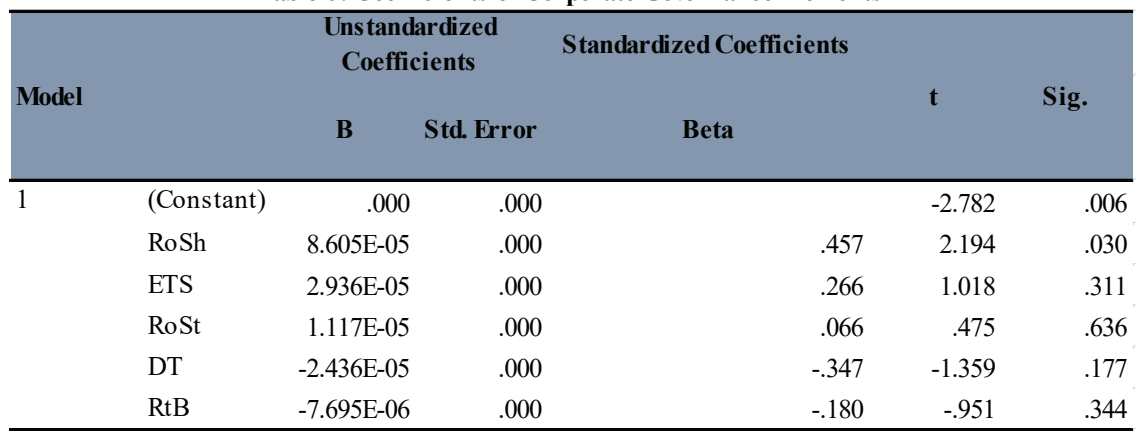

a. Dependent Variable: ERC

With a significance level 0.05 of probability, the result as in Table 6 indicated that Rights of Share Holders (RoSh) had a significant effect on ERC. The result indicated that there was a positive correlation between shareholder rights and ERC, thus supporting Hypothesis 1. It meant that when there is an increase in the value of the element of shareholder rights, it will also be followed by an increase in ERC and vice versa. These results are in line with Huang et al. (2010) and Ngamchom (2015).

Table 7: Coefficients of Dis closure of Corporate Governance

\begin{tabular}{|c|c|c|c|c|c|c|}
\hline \multirow{2}{*}{ Model } & & \multicolumn{2}{|c|}{$\begin{array}{l}\text { Unstandardized } \\
\text { Coefficients }\end{array}$} & Standardized Coefficients & \multirow{2}{*}{$\mathbf{t}$} & \multirow{2}{*}{ Sig. } \\
\hline & & B & Std. Error & Beta & & \\
\hline \multirow[t]{6}{*}{1} & (Constant) & -.001 & .000 & & -3.320 & .001 \\
\hline & GCG_D & $3.629 \mathrm{E}-06$ & .000 & .222 & 2.262 & .026 \\
\hline & ROA & .002 & .001 & 617 & 2.746 & .007 \\
\hline & $\mathrm{ROE}$ & .000 & .000 & -.644 & -1.958 & .053 \\
\hline & DLTR & .000 & .000 & .155 & 1.392 & .167 \\
\hline & DER & 4.087E-05 & .000 & .268 & 1.226 & .223 \\
\hline
\end{tabular}

a. Dependent Variable: ERC

With a significance level 0.05 of probability, the result as shown in Table 7 indicated that disclosure of corporate governance (GCG_D) and ROA had a significant effect on the ERC, thus supporting Hypothesis 6. The results indicated that there was a positive correlation between the total disclosure of corporate governance, ROA, and ERC. It meant that 
when there is an increase in the value of the total disclosure of corporate governance and ROA, it will also be followed by an increase in ERC and vice versa. These results are in line with Francis et al. (2006) and Mahjoubi and Abaoub (2015).

The overall results of the study indicated that the ASEAN CGSC has a significant positive effect on the ERC. This influence applies to the total overall corporate governance and one of its elements, namely, the right of shareholders. By referring to the ERC as a proxy of investor response, this showed that each element of the score on the ASEAN CGSC deserves attention and must be fulfilled and implemented as well as possible by a company because it is one of the indicators for investors in assessing a company. Investors will see the total score of corporate governance in responding to changes in the value of shares on the stock market. Not only that, companies also need to pay attention to the value of the rights of shareholders element. The total value of this element can convince investors about the certainty of their rights when making investments and it is likely that investors will respond positively to it.

\section{CONCLUSION}

This study aimed to answer the research questions regarding the effect of disclosure of corporate governance using the ASEAN CGSC and its elements on earnings quality. The results showed that there was a significant effect of corporate governance disclosures using the ASEAN CGSC on earnings quality. Meanwhile, in terms of the ASEAN CGSC elements, it was known that only the element of shareholder rights had a significant effect on earnings quality. Disclosures of corporate governance has an important role in relation to investors' decisions. This finding revealed that the element of shareholder rights is an important point for investors in relation to investment decisions. The disclosures related to equitable treatment, role of stakeholders, disclosure and transparency, and responsibilities of the board had no significant effect on earnings quality.

Based on the results of this research, it is suggested that management should provide a more comprehensive disclosure regarding the rights of shareholders. Transparency will increase investor confidence and reduce 
investment risks. Future studies can examine whether the ASEAN CGSC disclosures can reduce investment risks.

\section{REFERENCES}

Ali, C. B., \& Lesage, C. (2013). Audit pricing and nature of controlling shareholders: Evidence from France. China Journal of Accounting Research, 6(1), 21-34. doi: 10.1016/j.cjar.2012.08.002.

Banks, E. (2004). Corporate governance: Financial responsibility, controls and ethics. Hampshire, Palgrave MacMillan. https://doi. org/10.1057/9780230508101.

Bukit, R. B., \& Nasution, F. N. (2015). Employee diff, free cash flow, corporate governance and earnings management. Procedia-Social and Behavioral Sciences, 211, 585-594. doi: 10.1016/j.sbspro.2015.11.077.

Cheung, Y. L., Connelly, J. T., Estanislao, J. P., Limpaphayom, P., Lu, T., \& Utama, S. (2014). Corporate governance and firm valuation in Asian emerging markets. doi: 10.1093/oxfordhb/9780198743682.013.33.

Cupertino, C. M., Martinez, A. L., \& da Costa Jr, N. C. (2015). Earnings manipulations by real activities management and investors' perceptions. Research in International Business and Finance, 34, 309-323. doi: 10.1016/j.ribaf.2015.02.015.

Dechow, P., Ge, W., \& Schrand, C. (2010). Understanding earnings quality: A review of the proxies, their determinants and their consequences. Journal of Accounting and Economics, 50(2-3), 344-401. doi: 10.1016/j. jacceco.2010.09.001.

Dechow, P. M., \& Schrand, C. M. (2004). Earnings quality. Research Foundation of CFA Institute.

Demerjian, P. R., Lev, B., Lewis, M. F., \& McVay, S. E. (2013). Managerial ability and earnings quality. The Accounting Review, 88(2), 463-498. doi: 10.2308/accr-50318. 
Francis, J., Per, O., \& Katherine, S., (2006). Earning quality. Foundations and Trends in Accounting. 1(4), 259-340. doi: 10.1145/3132847.3132886.

Friedman, A. L., \& Miles, S. (2006). Stakeholders: Theory and practice. Oxford University Press.

Gaio, C., \& Raposo, C. C. (2014). Corporate governance and earnings quality: International evidence. Journal of Accounting and Finance, 14(3), 52-74. Available at: http://profdoc.um.ac.ir/paper-abstract-1035196. html

Garratt, B. (2003). Thin on top why corporate governance matters and how to measure and improve board performance. Nicholas Brealey.

Hashim, H. A., \& Devi, S. S. (2012). Institutional monitoring and earnings quality in Malaysia. Procedia-Social and Behavioral Sciences, 65, 419426. doi: 10.1016/j.sbspro.2012.11.143.

Huang, H. H., Wang, W., \& Zhou, J. (2010). The effect of shareholder rights and insider ownership on earnings management. SSRN Electronic Journal, (May 2015). doi: 10.2139/ssrn.1012874.

Huang, Z., \& Xue, Q. (2016). Re-examination of the effect of ownership structure on financial reporting: Evidence from share pledges in China. China Journal of Accounting Research, 9(2), 137-152. doi: 10.1016/j. cjar.2015.11.001.

Kamarudin, K. A., Ismail, W. A. W., \& Samsuddin, M. E. (2012). The influence of CEO duality on the relationship between audit committee independence and earnings quality. Procedia-Social and Behavioral Sciences, 65, 919-924. doi: 10.1016/j.sbspro.2012.11.220.

Kasim, E. (2015). Effect of implementation of good corporate governance and internal audit of the quality of financial reporting and implications of return of shares. International Journal of Scientific \& Technology Research, 4(9), 89-98. 
Kazemian, S., \& Sanusi, Z. M. (2015). Earnings management and ownership structure. Procedia Economics and Finance, 31, 618-624. doi: 10.1016/ S2212-5671(15)01149-1.

Latif, K., Bhatti, A. A., \& Raheman, A. (2017). Earnings quality: A missing link between corporate governance and firm value. Business \& Economic Review, 9(2), 255-280. doi: 10.22547/BER/9.2.11.

Mahjoubi, M., \& Abaoub, E. (2015). Earnings response coefficient as a measure of market expectations: Evidence from Tunis Stock Exchange. International Journal of Economics and Financial Issues, 5(2), 377-389. Available at: http://www.scopus.com/inward/record.u rl?eid=2-s2.0-84927946423\&partnerID $=40 \& \mathrm{md} 5=1470690 \mathrm{e} 384662$ f62b7da89ef6b8e04d.

Mangala, D., \& Kumari, P. (2015). Corporate fraud prevention and detection: Revisiting the literature. Journal of Commerce \& Accounting Research, 4(1), 35-45. doi: 10.21863/jcar/2015.4.1.006.

Mansor, N., Che-Ahmad, A., Ahmad-Zaluki, N. A., \& Osman, A. H. (2013). Corporate governance and earnings management: A study on the Malaysian family and non-family owned PLCs. Procedia Economics and Finance, 7, 221-229. doi: 10.1016/S2212-5671(13)00238-4.

Ngamchom, W. (2015). Impact of board effectiveness and shareholders structure on earnings management in Thailand. Review of Integrative Business and Economics Research, 4(2), 342-354. doi: 10.1016/j. geotexmem.2008.01.001.

Noor, N. F. M., Sanusia, Z. M., Heang, L. T., Iskandar, T. M., \& Isa, Y. M. (2015). Fraud motives and opportunities factors on earnings manipulations. Procedia Economics and Finance, 28, 126-135. doi: 10.1016/S2212-5671(15)01091-6.

Norwani, N. M., Zam, Z. M., \& Chek, I. T. (2011). Corporate governance failure and its impact on financial reporting within chosen companies. International Journal of Business and Social Science, 2(21), 205-213. 
Okolie, A. O. (2014). Audit quality and earnings response coefficients of quoted companies in Nigeria. Journal of Applied Finance and Banking, 4(2), 139-161. Available at: http://www.scienpress.c om/Upload/JAFB/ Vol 4_2_10.pdf.

Omar, N., Rahman, R. A., Danbatta, B. L., \& Sulaiman, S. (2014). Management disclosure and earnings management practices in reducing the implication risk. Procedia-Social and Behavioral Sciences, 145, 88-96. doi: 10.1016/j.sbspro.2014.06.014.

Roche, J. (2005). Corporate governance in Asia. Routledge.

Ronen, J., \& Yaari, V. (2008). Earnings management: Emerging insights in theory, practice and research. The International Journal of Accounting. doi: 10.1017/CBO9781107415324.004.

Shleifer, A., \& Vishny, R. W. (1986). Large shareholders and corporate control. Journal of Political Economy, 94(3, Part 1), 461-488. Available at: http://www.icfes.gov.co/examenes/component/docman / doc_download/253-competencias-ciudadanas-saber-pro?Itemid=.

Solomon, J., \& Solomon, A. (2004). Corporate governance and accountability. John Wiley and Sons Ltd.

Ugbede, O., Lizam, M., \& Kaseri, A. (2013). Corporate governance and earnings management: Empirical evidence from Malaysian and Nigerian banks. Asian Journal of Management Sciences and Education, 2(4), $1-21$.

UNCTAD, GDS \& MDPB (2010). The financial and economic crisis of 2008-2009 and developing countries. United Nations. Unctad/Gds/ $\mathrm{Mdp} / 2010 / 1$.

Uwuigbe, U., Peter, D. S., \& Oyeniyi, A. (2014). The effects of corporate governance mechanisms on earnings management of listed firms in Nigeria. Accounting and Management Information Systems, 13(1), 159-174. 
Xie, B., Davidson III, W. N., \& DaDalt, P. J. (2003). Earnings management and corporate governance: The role of the board and the audit committee. Journal of Corporate Finance, 9(3), 295-316. doi: 10.1016/ S0929-1199(02)00006-8.

Zhai, J., \& Wang, Y. (2016). Accounting information quality, governance efficiency and capital investment choice. China Journal of Accounting Research, 9(4), 251-266. doi: 10.1016/j.cjar.2016.08.001. 